\title{
Genomic Instability in Peripheral Blood and Buccal Mucosal Cells of Marijuana Smokers: The Impact of Tobacco Smoke
}

\author{
Daniel Vitor De Souza ${ }^{1}$, Samuel Rangel Claudio ${ }^{1}$, Camila Lima Feitosa Da Silva ${ }^{2}$, \\ Kevin Pereira Marangoni², Rogerio Correa Peres ${ }^{2}$, Daniel Araki Ribeiro ${ }^{1 *}$
}

\begin{abstract}
Background: The aim of this study was to evaluate cytotoxic, mutagenic and genotoxic effects on buccal mucosa and peripheral blood cells from marijuana and tobacco smokers. Methods: For this purpose, a total of 45 volunteers were distributed into four groups: CTRL group (control): individuals who did not smoke marijuana or tobacco $(\mathrm{n}=11)$; Group M: Marijuana smokers ( $\mathrm{n}=13)$; Group T: Tobacco smokers ( $\mathrm{n}=13)$; Group M + T: Smokers of both marijuana and tobacco $(\mathrm{n}=08)$. Results: Smokers of both marijuana and tobacco led an increase of micronucleated cells on buccal mucosa when compared to control group. The occurrence of karyolysis showed significant changes in this group as well. The comet assay data revealed genetic damage in peripheral blood cells for all groups of smokers. Conclusion: In summary, our results showed that marijuana and /or tobacco are able to induce genetic damage and cytotoxicity in oral and peripheral blood cells.
\end{abstract}

Keywords: Oral mucosa cells- peripheral blood- marijuana- tobacco smoke- micronucleus test

Asian Pac J Cancer Prev, 21 (5), 1235-1239

\section{Introduction}

The plant Cannabis sativa belongs to the family Cannabaceae L, popularly known as marijuana from Asian continent (Lopez et al., 2014). The harvest occurs in the fall to have a good concentration of its main bioactive compound, Delta-9-tetrahydrocannabinol (THC) (Lopez et al., 2014). To date, there are several variables for consuming the plant, such as inhalation (smoking), ingestion (use of the plant in homemade recipes, such as cakes and biscuits) and skin absorption (adhesives). It is important to stress that the consumption method chosen directly affects the onset of its effect as well as the amount of THC that will be absorbed by the organism. The inhalation promoted by cigarettes in dry form is widely used due to greater effectiveness. It is estimated that $0.5-1 \mathrm{~g}$ of the plant contains $20 \mathrm{mg}$ of THC. This in turn is consumed in the form of tetrahydrocannabinolic acid as a result of combustion of the plant (Bonfa et al., 2003). The acid then converts into free THC, where it is absorbed through inhalation; the smoke goes to the lungs allowing the bioactive substances to reach the bloodstream and central nervous system (Bonfa et al., 2003).

Marijuana is considered an illicit drug in many countries, such as Brazil, where it is widely consumed by people in general who justify its use to produce relaxation, and decreased stress and anxiety (Zuardi et al., 2010). Nevertheless, it has been documented that marijuana smoke promotes several harmful health effects (Lee and Hancox, 2011). In fact, some authors have postulated that marijuana smoke condensates contain similar chemical compounds as those detected in tobacco cigarette smoke (Moir et al., 2008). Many of them, have been classified as carcinogens by International Agency for Research on Cancer (IARC) (Smith et al., 2003). Herein, it would be important to know whether, and to what extent, marijuana smoke condensates, associated or not with tobacco cigarette smoke, could exert harmful effects on human health, especially on genetic material. This investigation is relevant since there are few studies investigating marijuana-only smoking populations as well as the association with tobacco cigarette smoke.

To date, some research groups have investigated putative biomarkers for biomonitoring continuous exposure of human populations to environmental mutagens and carcinogens (Maranho et al., 2017; Claudio et al., 2019). Among them, micronucleus and single cell gel comet assays are simple, low cost, reproducible and non-invasive methodologies for investigating cytogenetic damage and DNA strand breaks in eukaryotic cells, respectively (Tice et al., 2000; Bonassi et al., 2011). Previous studies conducted by our research group have demonstrated that micronucleus and single cell gel comet assays are important tools for biomonitoring people 
exposed to chemical agents and/or conditions considered to be suspect (Guilheiro et al., 2014; Souza et al., 2016; Andrade et al., 2017; Da Silva et al., 2018).

The aim of this study was to investigate geno- and cytotoxicity in buccal mucosa and peripheral blood cells from marijuana users associated, or not, with cigarette smoke by micronucleus and single cell gel comet assays.

\section{Materials and Methods}

\section{Participants}

For this study, a total of 45 volunteers were recruited. They were distributed into four groups, as follows: CTRL group (control): no smokers $(\mathrm{n}=11)$; Group M: Marijuana smokers $(\mathrm{n}=13)$; Group T: Tobacco smokers $(\mathrm{n}=13)$; Group $\mathrm{M}+\mathrm{T}$ : Smokers of both marijuana and tobacco $(\mathrm{n}=08)$. The study's eligibility criteria included: (iii) do not present chronic degenerative diseases, such as hypertension, diabetes or cancer, (iv) do not intake any medicines continuously; (v) do not present oral lesion when colleting oral cells; (vi) do not to be exposed to dental X-ray 1 month before collecting buccal cells; (vii) agree to participate in the study. Exposure to other known genotoxic agents, such as alcohol consumption was not recorded in this setting. The study was approved by the Ethics Committee of the University Sao Judas Tadeu, Campus UNIMONTE (Protocol number \#2.222.726). Informed consent was obtained from all individuals included in the study.

\section{Micronucleus test on oral mucosal cells}

Micronucleus test using buccal mucosa cells was made according to Belien et al., (1995). All slides were stained with Feulgen-Fast Green method being examined under a light microscope at $\times 1,000$ magnification. Micronuclei were identified according to the criteria described by Belien et al., (1995) as a parameter of DNA damage (mutagenicity). For cytotoxicity, the following nuclear alterations were considered: pyknosis, karyolysis and karyorrhexis (Tolbert et al., 1992). This analysis was performed by one experienced observer. A total of 2000 cells were evaluated per volunteer.

\section{Single cell gel comet assay in peripheral blood cells}

The single cell gel comet assay was performed to peripheral blood cells as described by Tice et al., (2000). A total of 25 comets were evaluated per volunteer. To measure the genotoxicity, tail moment was chosen. This is defined as the product between \% comet tail and DNA migration. The value was expressed to arbitrary units.

\section{Statistical methods}

The Kruskall-Wallis non-parametric test followed by Dunn's test were used to compare the frequencies of cytotoxicity among the samples between the experimental group versus control group. Micronucleus frequencies among groups were evaluated as established by Pereira (1991). The tail moment data was evaluated by two-way ANOVA (analysis of variance) followed by Tukey's test. The statistical analysis was conducted using BioStat software version 5.0 (Maringa. PR. Brazil). The level of significance was set at $5 \%$.

\section{Results}

The demographic characteristic for all participants are presented in Table 1.

The results of this study demonstrated that marijuana did not increase the total number of micronucleated cells. Cytotoxicity did not show statistically significant differences $(p>0.05)$. Such findings are demonstrated in Table 2.

As it was evidenced with marijuana smokers, Tobacco cigarette smokers did not show any significant differences with respect to the number of micronucleated cells when compared to control group. Regarding metanuclear changes indicative of cytotoxicity, the same picture occurred, i.e. no statistically significant differences $(\mathrm{p}>0.05)$ were found to pyknosis, karyorrhexis and karyolysis.

Interestingly, smokers of both marijuana and Tobacco demonstrated an increase of micronucleated cells when compared to control group $(\mathrm{p}<0.05)$. For cytotoxicity, the occurrence of karyolysis showed significant changes $(p<0.05)$ as well. With respect to pyknosis and karyorrhexis, no remarkable changes $(\mathrm{p}>0.05)$ were detected in this group. Such findings are shown in Table 2. Figure 1 illustrates all metanuclear changes considered in this study (pyknosis, karyorrhexis, karyolysis and micronucleus).

Finally, the single cell gel comet assay data revealed that all experimental groups showed DNA damage in peripheral blood cells. Statistically significant differences $(p<0.05)$ were noticed with marijuana and/or Tobacco smokers when compared to control group. These findings are demonstrated in Figure 2.

Table 1. Demographic Characteristics from All Participants of the Study

\begin{tabular}{lcccc}
\hline Groups & $\mathrm{CTRL}(\mathrm{n}=11)$ & $\mathrm{M}(\mathrm{n}=13)$ & $\mathrm{T}(\mathrm{n}=13)$ & $\mathrm{M}+\mathrm{T}(\mathrm{n}=08)$ \\
\hline Age (years) & $21+8.1$ & $25+6.9$ & $22+3.0$ & $26+8.7$ \\
Gender & $\mathrm{M} / \mathrm{F}$ & $\mathrm{M} / \mathrm{F}$ & $\mathrm{M} / \mathrm{F}$ & $\mathrm{M} / \mathrm{F}$ \\
& $4 / 7$ & $9 / 4$ & $5 / 8$ & $1 / 7$ \\
Average user time of Marijuana (years) & - & 6.76 & 7.92 & 11 \\
Average user time of Tobacco (years) & - & - & - & 9 \\
Frequency of use of Marijuana & - & From 1 to 7 days a week & From 2 to 7 days per week & 7 days per week \\
Frequency of use of Tobacco & - & - & &
\end{tabular}


Table 2. Mean and S.D of Pyknosis, Karrhyorexis, Karyolysis and Micronucleus on Buccal Mucosa Cells of Marijuana and/or Tobacco Users

\begin{tabular}{lcccc}
\hline Groups & Pyknosis & Karrhyorexis & Karyolysis & Micronucleus \\
\hline CTRL & $272.5 \pm 193.5$ & $5.54 \pm 8.21$ & $430.2 \pm 522.5$ & $0.10 \pm 0.15$ \\
M & $177.9 \pm 216.3$ & $7.15 \pm 9.90$ & $618.9 \pm 512.6$ & $0.15 \pm 0.37$ \\
T & $56.54 \pm 79.06$ & $4.53 \pm 3.88$ & $350.8 \pm 317.3$ & $0.23 \pm 0.59$ \\
M+T & $114.5 \pm 137.3$ & $2.62 \pm 3.62$ & $1045 \pm 417.6^{*}$ & $0.50 \pm 1.06^{*}$ \\
\hline
\end{tabular}

CTRL, control group; M, marijuana group; T, tobacco group; $\mathrm{M}+\mathrm{T}$, marijuana and tobacco group; *p $<0.05$ when compared to control group

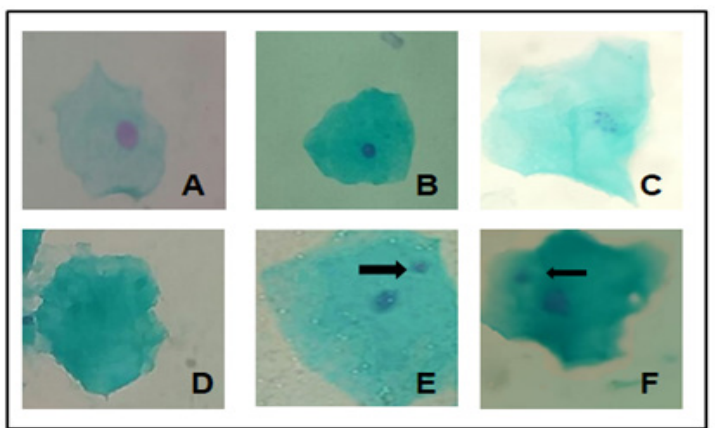

Figure 1. Photomicrography of Oral Mucosa Cells Cells Showing Metanuclear Changes. (A), Normal cell; (B), Pyknosis; (C), Karyorrhexis; (D), Karyolysis; E and F, Micronucleus (arrow). Feulgen-Fast green staining. X100 magnification.

\section{Discussion}

The main results of this study revealed that smokers of both marijuana and tobacco led an increase of micronucleated cells on buccal mucosa as well as DNA breakage in peripheral blood cells. There are few studies regarding the consumption of marijuana smoke condensates since the majority of investigations are conducted with isolated compounds, such as $\triangle 9-\mathrm{THC}$ or cannabidiol.

First, our results revealed that marijuana was able to induce genetic damage in peripheral blood cells. However, it not possible to identify an increase in the frequency of micronucleated cells on buccal mucosa in marijuana smokers. In a similar way, no significant differences with respect to cytotoxicity were detected. Having searched the scientific literature, it was noted that the genotoxicity of marijuana has been well documented. DNA damage in macrophages from the lungs of marijuana smokers was found by some authors (Sherman et al. 1995). Marijuana smoke condensates were mutagenic in the Ames test as well (Maertens et al., 2009). Some components induced cytogenetic damage in mammalian cells in vivo and in vitro (Maertens et al., 2013; Lucić Vrdoljak et al., 2019; Russo et al., 2019). Moreover, non-mammalian species demonstrated positive genotoxicity induced by marijuana (Parolini et al., 2017). An epidemiological study showed that the continuous use of cannabis has a mutagenic effect (Zhang et al., 1999). Following the rationale, several biological mechanisms have been proposed for elucidating the genotoxicity induced by marijuana, such as the generation of reactive oxygen species (ROS) and deregulation of apoptosis by means of abnormal p53 expression (Kim et al., 2013). It has been demonstrated that a brief exposure to Cannabis sativa induced the

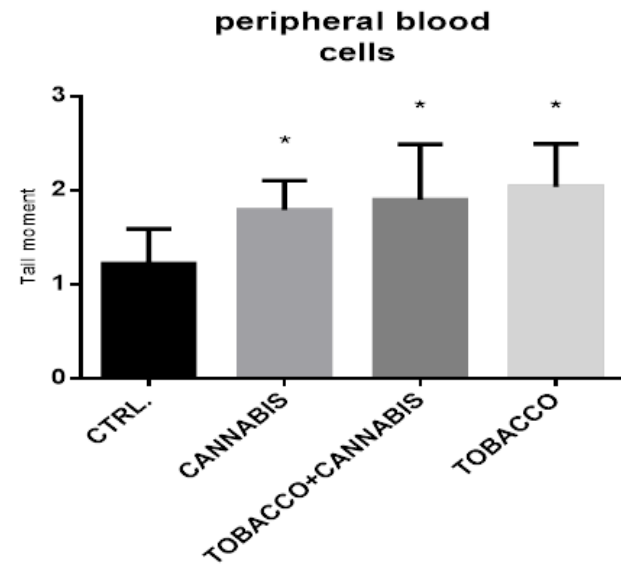

Figure 2. Single Cell Gel Comet Assay Data (Tail Moment) in Peripheral Blood Cells from Marijuana and/ or Tobacco Users. Results are expressed as Mean \pm S.D. $\mathrm{P}<0.05$ when compared to control group.

formation of ROS associated with significant reduction of GSH levels, leading to oxidative stress in the cell (Sarafian et al., 1999). Probably, the quantity of tobacco cigarettes smoked by people was not enough to demonstrate an in vivo effect in this setting. Further studies are necessary to clarify the issue.

The results obtained from the tobacco cigarette smokers failed to detect a positive effect in the micronucleus assay. Regarding cytotoxicity, no significant changes were detected by means of pyknosis, karyolysis and karyorrhexis in this study. However, tobacco cigarette smokers presented genetic damage in peripheral blood cells. Tobacco smoke is able to deregulate intrinsic apoptosis pathways, and to modulate the expression of some xenobiotics metabolizing proteins (Assis et al., 2005; Ribeiro and Assis, 2008). Furthermore, the biological relevance of tobacco cigarette smoke, when studying the micronucleus assay on oral cells, is well established in scientific literature. It seems that tobacco cigarette smoke induces metanuclear changes in buccal mucosa cells (Nersesyan et al., 2006; Pereira da Silva et al., 2015; Metgud and Neelesh, 2018). Nevertheless, Nersesyan et al., (2011) have postulated that the occurrence of such nuclear alterations is dependent on type and quantity of tobacco cigarettes smoked per day. Therefore, it is assumed that the number of cigarettes consumed is mandatory for detecting any biological effect. Certainly, this explains our results since the participants smoke only a few cigarettes per day.

Considering that a large number of marijuana smokers are also tobacco cigarette smokers, we decided to investigate the combination of the two. Our results revealed the presence of DNA strand breaks in peripheral 
blood cells and increased number of micronucleated cells in this group. An increase in the frequency of karyolysis was also found in these volunteers as well. Some authors have revealed analogous compounds between marijuana and tobacco smoke products (Maertens et al., 2009). Such information helps to explain that the association plays an important role for genotoxic, mutagenic and cytotoxic properties exerted by marijuana on oral and peripheral blood cells. In fact, some authors pointed out the positive correlation between cannabis and cancer. Hirao-Suzuki (2019) showed that $\triangle 9$-THC increases fatty acid 2-hydroxylase $(F A 2 H)$ expression in human breast cancer cells. Murphy et al., (2019) have assumed that cannabis use was associated with significantly lower sperm concentration and Callaghan et al., (2011) recently found a link between cannabis consumption and testicular cancer. However, some studies have postulated that cannabis inhibited tumor development. Shrivastava et al., (2011) have demonstrated that cannabidiol is able to kill breast cancer cells by inducing oxidative stress and inhibiting mTOR signaling. One possible explanation for these controversial results may be the form of administration of cannabis. When smoked, cannabis seems to lose its protective effects as far as to induce harmful effects. When both are smoked, our results demonstrate that marijuana smoke condensates, when associated with cigarette smoke, induce genetic damage and cellular death in peripheral blood and buccal mucosal cells.

In summary, our results showed that a combination of marijuana and tobacco smoking habits is able to induce genomic instability in peripheral blood and buccal mucosa cells. Certainly, this comprises a risk condition for chemical carcinogenesis. Even so, it is important to stress the difficulty in designing the study. This is because the consumption of marijuana is illegal here in Brazil. Therefore, recruiting volunteers to join and participate was quite complicated in this study. For this reason, the number of volunteers was relatively small. Further analysis with a larger sample of volunteers continuously exposed to cannabis is interesting as a future perspective to confirm the data obtained.

\section{Acknowledgments}

DAR is the recipient of the CNPq (Conselho Nacional de Desenvolvimento Cientifico e Tecnologico) productivity fellowship. DVS and SRC are recipients of the CAPES (Coordenação de Aperfeiçoamento de Nivel Superior) student fellowships.

\section{Conflict of interest statement}

None declared.

\section{References}

Andrade MC, Dos Santos JN, Cury PR, et al (2017). Cytogenetic biomonitoring in buccal mucosal cells from municipal solid waste collectors. Anticancer Res, 372, 849-52.

Assis GF, Ceolin DS, Marques ME, Salvadori DM, Ribeiro DA (2005). Cigarette smoke affects apoptosis in rat tongue mucosa, role of bcl-2 gene family. J Mol Histol, 36, 483-9.
Beliën JA, Copper MP, Braakhuis BJ, Snow GB, Baak JP (1995). Standardization of counting micronuclei, definition of a protocol to measure genotoxic damage in human exfoliated cells. Carcinogenesis, 1610, 2395-400.

Bonassi S, Coskun E, Ceppi M, et al (2011). The HUman MicroNucleus project on eXfoLiated buccal cells HUMNXL, the role of life-style, host factors, occupational exposures, health status, and assay protocol. Mutat Res, 7283, 88-97.

Bonfa L, Viagre RCO, Figueiredo NV (2003). Uso de canabinóides na dor crônica e em cuidados paliativos. Rev Bras Anestesiol, 58, 267-79 in Portuguese.

Callaghan RC, Allebeck P, Akre O, Mcglynn, KA, Sidorchuk A (2011). Cannabis use and incidence of testicular cancer, A 42-year follow-up of Swedish men between 1970 and 2011. Cancer Epidemiol Biomarkers Prev, 26, 110-7.

Claudio SR, Simas JMM, Souza ACF, et al (2019). Genomic instability and cytotoxicity in buccal mucosal cells of workers in Banana farming evaluated by micronucleus test. Anticancer Res, 39, 1283-6.

Da Silva VHP, Andrade MC, Claudio SR, et al (2018). Genomic instability in buccal mucosal cells of municipal street sweepers as evaluated by micronucleus test. Anticancer Res, 385, 3123-6.

Guilheiro JM, Chaves MD, Martins AM, Ribeiro DA, D'Almeida V (2014). Cytogenetic biomonitoring in mucopolyssacharosis I, II and IV patients treated with enzyme replacement therapy. Toxicol Mech Methods, 24, 603-7.

Hirao-Suzuki M, Takeda S, Watanabe K, Takiguchi M, Hironori A (2019). $\Delta$-Tetrahydrocannabinol upregulates fatty acid 2-hydroxylase FA2H via PPAR $\alpha$ induction, A possible evidence for the cancellation of PPAR $\beta / \hat{I}^{\prime}$-mediated inhibition of PPAR $\alpha$ in MDA-MB-231â-cells. Arch Biochem Biophys, 662, 19-25.

Kim HR, Jung MH, Lee SY, Oh SM, Chung KH (2013). Marijuana smoke condensate induces p53-mediated apoptosis in human lung epithelial cells. J Toxicol Sci, 383, 337-47.

Lee MH, Hancox RJ (2011). Effects of smoking cannabis on lung function. Expert Rev Respir Med, 5, 537-47.

López GE, Brindis F, Cristians NS, Martinez RV (2014). Cannabis Sativa L, uma planta singular. Rev Mex Cien Farm Mexico, 45, 1-6.

Lucić Vrdoljak A, Fuchs N, Mikolić A, et al (2019). Irinotecan and $\Delta$-Tetrahydrocannabinol interactions in Rat liver, A preliminary evaluation using biochemical and genotoxicity markers. Molecules, in press.

Maertens RM, White PA, Rickert W, et al (2009). The genotoxicity of mainstream and sidestream marijuana and tobacco smoke condensates. Chem Res Toxicol, 228, 1406-14.

Maertens RM, White PA, Williams A, Yauk CL (2013). A global toxicogenomic analysis investigating the mechanistic differences between tobacco and marijuana smoke condensates in vitro. Toxicology, 308, 60-73.

Maranho LA, Fontes MK, Kamimura ASS, et al (2017). Exposure to crack cocaine causes adverse effects on marine mussels Perna perna. Mar Pollut Bull, 123, 410-4.

Metgud R, Neelesh BT (2018). Effect of staining procedures on the results of micronucleus assay in the exfoliated buccal mucosal cells of smokers and nonsmokers, A pilot study. $J$ Cancer Res Ther, 142, 372-6.

Moir D, Rickert WS, Levasseur G, et al (2008). A comparison of mainstream and sidestream marijuana and tobaccocigarette smoke produced under two machine smoking conditions. Chem Res Toxicol, 21, 494-502.

Murphy SK, Itchon-Ramos N, Visco Z, et al (2019). Cannabinoid 
exposure and altered DNA methylation in rat and human sperm. Epigenetics. in press.

Nersesyan A, Kundi M, Atefie K, Schulte-Hermann R, Knasmüller S (2006). Effect of staining procedures on the results of micronucleus assays with exfoliated oral mucosa cells. Cancer Epidemiol Biomarkers Prev, 1510, 1835-40.

Nersesyan A, Muradyan R, Kundi M, Knasmueller S (2011). Impact of smoking on the frequencies of micronuclei and other nuclear abnormalities in exfoliated oral cells, a comparative study with different cigarette types. Mutagenesis, 262, 295-301.

Parolini M, Castiglioni S, Magni S, Della Torre C, Binelli A (2017). Increase in cannabis use may indirectly affect the health status of a freshwater species. Environ Toxicol Chem, 362, 472-9.

Pereira da Silva VH, de Luna Antonio R, Pompeia S, Ribeiro DA (2015). Cytogenetic biomonitoring in buccal mucosa cells from young smokers. Acta Cytol, 596, 474-8.

Pereira. CAB (1991). Teste estatístico para comparar proporções em problemas de citogenética In, Rabelo-Gay N. Rodrigues MA and Monteleone-Neto R eds. Mutagênese. Teratogênese e Carcinogênese. SBG. pp 113-21 in Portuguese.

Ribeiro DA, Assis GF (2008). Expression of placental glutathione S-transferase in rat tongue mucosa exposed to cigarettesmoke. J Mol Histol, 391, 115-9.

Russo C, Ferk F, Mišík M, et al (20190. Low doses of widely consumed cannabinoids cannabidiol and cannabidivarin cause DNA damage and chromosomal aberrations in human-derived cells. Arch Toxicol, 931, 179-88.

Sarafian TA, Magallanes JAM, Shau H, Tashkin D, Roth MD (1999). Oxidative stress produced by marijuana smoke in adverse effect enhanced by cannabinoids. Am J Respir Cell Mol Biol, 20, 6.

Sherman MP, Aeberhard EE, Wong VZ, et al (1995). ffects of smoking marijuana, tobacco or cocaine alone or in combination on DNA damage in human alveolar macrophages. Life Sci, 5623, 2201-7.

Shrivastava A, Kuzontkoski PM, Groopman JE, Prasad AA (2011). Cannabidiol induces programmed cell death in breast cancer cells by coordinating the cross-talk between apoptosis and autophagy. Mol Cancer Ther, 10, 1161-72.

Smith CJ, Perfetti TA, Garg R, Hansch C (2003). IARC carcinogens reported in cigarette mainstream smoke and their calculated $\log \mathrm{P}$ values. Food Chem Toxicol, 41, 807-17.

Souza AC, DA Silva VH, Seixas C, et al (2016). Cytogenetic biomonitoring in buccal mucosa cells from women submitted to chemotherapy after mastectomy for breast cancer. Anticancer Res, 364, 1955-8.

Tice RR, Agurell E, Anderson D, et al (2000). Single cell gel/ comet assay, guidelines for in vitro and in vivo genetic toxicology testing. Environ Mol Mutagen, 353, 206-21.

Tolbert PE, Shy CM, Allen JW (1992). Micronuclei and other nuclear anomalies in buccal smears, methods development. Mutat Res, 271, 69-77.

Zhang ZF, Morgenstern, H, Spitz, MR, et al (1999). Marijuana use and increased risk of squamous cell carcinoma of the head and neck. Cancer Epidemiol Biomakers Prev, 8, 1071-8.

Zuardi AW, Crippa JSS, Hallak JEC (2010). Cannabis sativa, a planta que pode produzir efeitos indesejáveis e também tratá-los. Rev Bras Psiquiatr, 32, 51-2 in Portuguese.

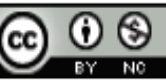

This work is licensed under a Creative Commons AttributionNon Commercial 4.0 International License. 